\title{
Utilization of Nkpuma-Akpatakpa clay in ceramics: characterization and micro- structural studies
}

\section{${ }^{1}$ ITUMA, CG; ${ }^{2}$ ETUKUDOH, AB; ${ }^{2 * A B U H, ~ M A ; ~}{ }^{3}$ AKPOMIE, KG; ${ }^{4}$ OBIOHA, CI}

\author{
${ }^{I}$ Department of Physics, Ebonyi State University (EBSU), Abakaliki, Ebony state, Nigeria \\ ${ }^{2}$ Department of Ceramics Research and Production, Projects Development Institute, Enugu State, Nigeria \\ ${ }^{3}$ Department of Pure \& Industrial Chemistry, University of Nigeria, Nsukka, Nigeria \\ ${ }^{4}$ Department of Chemical Engineering, Enugu State University of Science and Technology, Enugu, Nigeria \\ *E-mail: markabuh1@gmail.com
}

\begin{abstract}
Nkpuma - Akpatakpa clay was analysed for its ceramics suitability. Chemical, mechanical and spectral characterization of the clay was carried out to obtain more information from this clay found in commercial quantity at Ebonyi State Nigeria. The XRD analysis showed that the principal minerals in the clay are quartz, qandilite, aragonite, Muscovite and anatase. FTIR showed the stretching vibrations for $\mathrm{Si}-\mathrm{O}$ at $685.8 \mathrm{~cm}^{-1}$ showing the presence of Quartz. The frequency at $1431 \mathrm{~cm}^{-1}$ is due to $\left(\mathrm{CO}_{3}\right)^{2-}$ stretching mode vibration or $\mathrm{C}-\mathrm{O}$ stretching of Aragonite and the band at 2467.6 is due to $\mathrm{OH}$ - stretching. Bands observed at 984.7 and $987.7 \mathrm{~cm}^{-1}$ correspond to $\mathrm{Al}-\mathrm{O}$ bending vibrations which suggest the presence of muscovite in the clay and SEM studies were also carried out and reported. Porosity of the clay was $0.88 \%$ considered too small for refractory, thermal insulation and other high porosity desired ceramics applications. Value obtained for $\mathrm{Fe}_{2} \mathrm{O}_{3}$ was $>1.7 \%$ which accounted for why the clay did not fire white. The values for M.O.R was $>40 \mathrm{KgF} / \mathrm{cm}^{2}$. The refractoriness was $<1340^{\circ} \mathrm{C}$. Chemical characterization showed the presence of fluxing oxides at elevated levels which are responsible for the poor refractoriness and limits the utilization of the clay to low or mid-temperature ceramics products.
\end{abstract}

DOI: https://dx.doi.org/10.4314/jasem.v22i1.9

Copyright: Copyright $\left.{ }^{(}\right) 2017$ Ituma et al. This is an open access article distributed under the Creative Commons Attribution License (CCL), which permits unrestricted use, distribution, and reproduction in any medium, provided the original work is properly cited

Dates: Received 05 November 2017; received in revised form 09 December 2017; accepted 22 December 2017

Keywords: Nkpuma-Akpatakpa clay, Ceramics, Characterization, Qandilite, FTIR, Bulk density

Clays come in different colours depending on the inorganic impurities, organic matters and minerals inherent in them. They are anhydrous complexes of alumina $\left(\mathrm{Al}_{2} \mathrm{O}_{3}\right)$ and silica $\left(\mathrm{SiO}_{2}\right)$ generally represented by the molecular formula $\mathrm{Al}_{2} \mathrm{O}_{3} \cdot 2 \mathrm{SiO}_{2} \cdot 2 \mathrm{H}_{2} \mathrm{O}$. Investigations have been conducted into clays found in Nigeria, for their different applications (Elueze et al., 1999; Gbadebo, 2002; Irabor, 2002; Lawal and Abdullahi, 2010; Abuh et al., 2014). Consequently, such clays as Adiabo clay, Nsu clay, Ukpor clay, Enugu fireclay, Jos kaolin, Afuze clay, Usen clay, Uzalla clay, Kankara kaolin, Getzo kaolin and many more have been characterized and found useful applications for pottery and refractory (Abuh et al., 2014). There are vast deposits of clays spread across Nigeria, each differing from site to site on account of geological formation and location. Clay especially Kaolinite (china clay) was imported as previous reports claimed that Nigerian clays lacked the desire mechanical properties and mineralogical contents. The claim has long been negated as deposits discovered besides being of commercial quantity have been successfully applied for every form of ceramics. Local demands for ceramic products continued to soar considering the population yet the supply is met through importation. Also, worrisome is the fact that most of the imported ceramics are made with colors, glazes and body recipes considered toxic to humans and environment. The growth and demand for ceramics in Nigeria has encouraged the need to research and report more available options to avoid importation of materials which can be locally sourced and available. Ebonyi state in southeast Nigeria is not oil producing state but blessed with solid minerals such as uranium, limestones, galena, magnesite e.t.c. Only few types of clay of Ceramics value and in commercial quantity have been reported for the state which does not include clay from Nkpuma - Akpata communities. The mining activities in Nkpuma-Akpatakpa areas of the state has drawn attention to prospect for other minerals in this locality including the clays found in commercial quantity.

NkpumaAkpatakpa clay is relatively abundant and in commercial quantity found at Izzi Local Government Area of Ebonyi State, South - East Nigeria. The clay has been extensively used for the production of ceramic wares such as pots, flower vases, and glazes e.t.c but no detailed study of its characteristics and composition has been documented. This study aims to establish the 
mechanical and micro-structural profile with a view to suggesting other applications for the clay.

\section{MATERIALS AND METHODS}

The clay sample used in this research was obtained from different locations in NkpumaAkpatakpa at a depth of $1.52 \mathrm{~m}$ to get a good representation of the site and brought to the Ceramics Research and Production Laboratory of Projects \& Development Institute (PRODA), a research institute under the Federal ministry of Science and Technology, located in Enugu, south eastern Nigeria for detailed study.

Characterization of Clay Sample: The physical, chemical, mineralogical and micro-structural profile was carried out in the ceramics research and production department of the research institute. The results generated were compared with standards in literature, to ascertain the suitability of this clay for industrial utilization.

Experimental procedures for the physical analysis of clay: The sample was processed as described by Abuh et al (2014) but with little modification. Dry processing was employed. Clay obtained was air dried, pulverized and sieved using $0.35 \mathrm{~mm}$ mesh to remove unwanted particles and plant materials, then oven-dried at $110^{\circ} \mathrm{C}$ to constant weight. The dried clay was again pulverized and sieved using a $0.18 \mathrm{~mm}$ mesh. The pulverized clay was stored in moisture free environment for the study. A portion of the sample was then weighed out and mixed with calculated amount of water to achieve mouldability for the testing process.
Sample Preparation for structural analysis: The processed powdered sample was prepared for X-ray Diffraction (XRD), Scanning Electron Microscopy (SEM), and FTIR. The FTIR analysis was also carried out in accordance with standard for testing of ceramics materials (AOAC, SON).For the Scanning Electron Microscopy, SEM model JEOL 840 was used. The mineral phases within the samples were identified by powdered X-ray diffractometry method. The samples were first subjected to X-ray scanning using the Philips PW 1830 X-ray diffractometry with a cu-anode. Thereafter, mineral peaks were identified using XPert High Score plus Software.

Mechanical test:This was carried out to determine the Flexural strength, Water absorption, Linear (dry - fired) shrinkage, apparent porosity, bulk density, apparent density and forming pressure, and other properties of the clay. Methods employed were as described (Abuh et al., 2014)

\section{RESULTS AND DISCUSSION}

Raw Materials: We observe a change in the colour of the test bricks from brown to ox blood with increase in Temperature, a very usual observation. The change in colour might indicate the presence of lots of transitional elements in the body (Benneth, 2008; Fakolujo et al., 2012).

Chemical analysis: The oxide composition of the sample is shown in table1.

Tab 1: Chemical profile of Nkpuma Akpatakpa clay compared with some standard clays for industrial application (Grimshaw, 1971; Chester, 1973; Abubakar et al., 2014).

\begin{tabular}{llllllll}
\hline $\begin{array}{l}\text { Oxide } \\
(\%)\end{array}$ & Ceramics & $\begin{array}{l}\text { Refractory } \\
\text { bricks }\end{array}$ & $\begin{array}{l}\text { High melting } \\
\text { clay }\end{array}$ & Glass & Paper & Paint & $\begin{array}{l}\text { Nkpuma- } \\
\text { Akpatakpa }\end{array}$ \\
\hline $\mathrm{SiO}_{2}$ & 60.50 & $51-70$ & $53-73$ & $80-95$ & $45.0-45.8$ & $45.3-47.9$ & 53.92 \\
$\mathrm{Al}_{2} \mathrm{O}_{3}$ & 26.50 & $25-44$ & $16-29$ & $12-17$ & $33.5-36.1$ & $37.9-38.4$ & 21.43 \\
$\mathrm{Fe}_{2} \mathrm{O}_{3}$ & $0.5-1.2$ & $0.5-2.4$ & $1-9$ & $2-3$ & $0.3-0.6$ & $13.4-13.7$ & 7.28 \\
$\mathrm{CaO}$ & $0.18-3$ & $0.10-2.0$ & $0.5-2.6$ & $4-5$ & $0.03-0.60$ & $0.03-0.60$ & 5.33 \\
$\mathrm{MgO}$ & & & & & & - & 4.12 \\
$\mathrm{~K}_{2} \mathrm{O}$ & & & & & - & - & 1.25 \\
$\mathrm{Na}_{2} \mathrm{O}$ & & & & & & - & 0.19 \\
$\mathrm{TiO}_{2}$ & & & & & & & 4.32 \\
\hline
\end{tabular}

Key:- not available

The clay contains elevated levels of fluxing oxides such as $\mathrm{Fe}_{2} \mathrm{O}_{3}, \mathrm{CaO}, \mathrm{MgO}$, and $\mathrm{K}_{2} \mathrm{O}$. These fluxing agents pull down the vitrification temperature of ceramics bodies on addition of the clay. Silica content of clay above $46.5 \%$ indicates free silica (Quartz) in the system which will enhance the ceramic properties (Singer and Singer, 1993; Nwannenna et al, 2015).
The Alumina content of $21.43 \%$ is slightly below the standard for ceramics, refractory, paper, and paints (Chester, 1973; Abubakar et al, 2014). The lower the Alumina content, the lower the coefficient of thermal expansion of ceramic bodies. This may be due to the coupling reaction between $\mathrm{Al}^{3+}$ and $\mathrm{K}^{+}$in the system (Nwannenna et al., 2015). The clay is still suitable for production of fibreglasses and high melting clays as 
$\mathrm{Al}_{2} \mathrm{O}_{3}$ requirements are $12-17 \%$ and $16-29 \%$ respectively. Refractory clays need high alumina content. The higher the alumina content of clay the higher its suitability for refractory applications and the higher the refractoriness.

The $\mathrm{Fe}_{2} \mathrm{O}_{3}$ content was $7.28 \%$ which is higher than 0.5 $-2.4 \%$ being permissible limits for refractory bricks [Abubakar etal, 2014]. The composition of $\mathrm{Fe}_{2} \mathrm{O}_{3}<$ $2 \%$ means clay will fire white while $\mathrm{Fe}_{2} \mathrm{O}_{3}>2 \%$ means clay will change colour to brownish or ruby-red depending on the percentages involved (Singer and Singer, 1993; Gupta, 2008). The high content in this sample $(7.28 \%)$ may account for why it fired oxblood.

The values obtained for $\mathrm{CaO}$ and $\mathrm{MgO}$ were considered high enough for higher shrinkage to be observed. The higher the percentages of $\mathrm{CaO}$ and $\mathrm{MgO}$ in clay, the more likely the shrinkage. The combined value of $\mathrm{CaO}$ and $\mathrm{MgO}$ was $9.45 \%$ which is relatively high. The presence of quartz $\left(\mathrm{SiO}_{2}\right)$, muscovite and anatase $\left(\mathrm{TiO}_{2}\right)$ which are glass formers accounted for why the clay did not show much shrinkage.

Physical and mechanical properties of the fired test pieces: The summary of the mechanical behavior of the sample at $1250^{\circ} \mathrm{C}$ is presented in table 2.

Table 2: Mechanical profile of Nkpuma-Akpatakpa clay compared with some Ceramics standards for industrial applications (Omowunmi, 2000; Abubakar et al., 2014).

\begin{tabular}{lll}
\hline Sample description & $\begin{array}{l}\text { Nkpuma- } \\
\text { Akpatakpa } \\
(\mathbf{1 2 5 0} \mathbf{C})\end{array}$ & Ceramics \\
\hline Apparent porosity (\%) & 0.88 & $10-30$ \\
Water Absorption (\%) & 0.44 & - \\
Apparent Density & 2.01 & - \\
Bulk Density & 1.99 & 2.3 \\
Modulus of Rupture $\left(\mathrm{KgF} / \mathrm{Cm}^{2}\right)$ & $>40.31$ & - \\
Cold-crushing strength $\left(\mathrm{KN} / \mathrm{M}^{2}\right)$ & 1430 & \\
@ 900 ${ }^{\circ} \mathrm{C}$ & & \\
Modulus of plasticity (\%) & 1.36 & - \\
Linear Shrinkage (\%) & 6 & - \\
Bulk Volume (Cm $\left.{ }^{3}\right)$ & 35.83 & - \\
Apparent solid Volume $\left(\mathrm{Cm}^{3}\right)$ & 35.51 & - \\
Making Moisture $(\%) @ 30^{\circ} \mathrm{C}$ & 36.75 & - \\
Water of plasticity(\%) @ 30 $30^{\circ} \mathrm{C}$ & 36.67 & - \\
Refractoriness(0C) & 1350 & $>1500$ \\
\hline
\end{tabular}

Key: - not available

Flexural strength: The plot is shown in ceramics are shown in figure $1 \mathrm{~A}$.

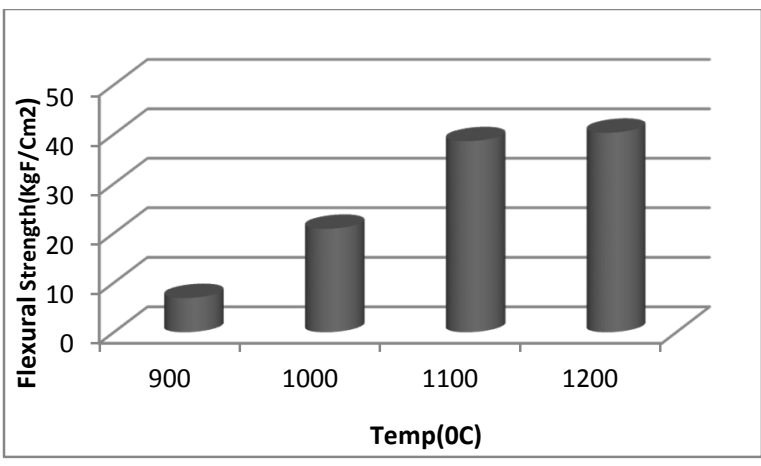

Fig 1 : Flexural strength (F.S) as a function of temperature

F.S increased with increase in temperature. The presence of quartz and muscovite tends to increase the amount of free silica present which melts with increase in temperature to form a uniform dense structure that greatly confers strength on the body. The presence of Anatase and qandilite which are regarded as glass formers may have interacted at high temperature to form a uniform crystalline layer that greatly increased the strength of the clay.

Linear shrinkage: The linear shrinkage increased with increase in temperature as shown in figure 2

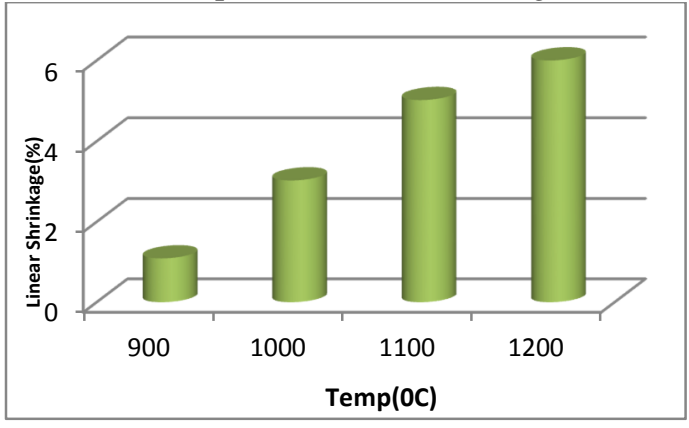

Fig 2: linear shrinkage (LS) as a function of Temperature

Value at $1200^{\circ} \mathrm{C}$ was $6 \%$ which is below the internationally accepted range of $7-10 \%$ recommended for linear shrinkage for refractory clays (Chester, 1973, Musa et al., 2012). The low shrinkage value suggests the muscovite content of the clay is high since it's a non-expansive material due to the $\mathrm{Si}$ - O bond. Fireclays have a recommended range of 4 - 10\% (Omowunmi, 2000; Musa et al., 2012). High shrinkage values are not desirable as it causes cracks due to body compression and consequently a change in the bulk volume.

Apparent porosity: The porosity decreased with increase in temperature as shown in figure 3. 
Utilization of Nkpuma-Akpatakpa clay in.....

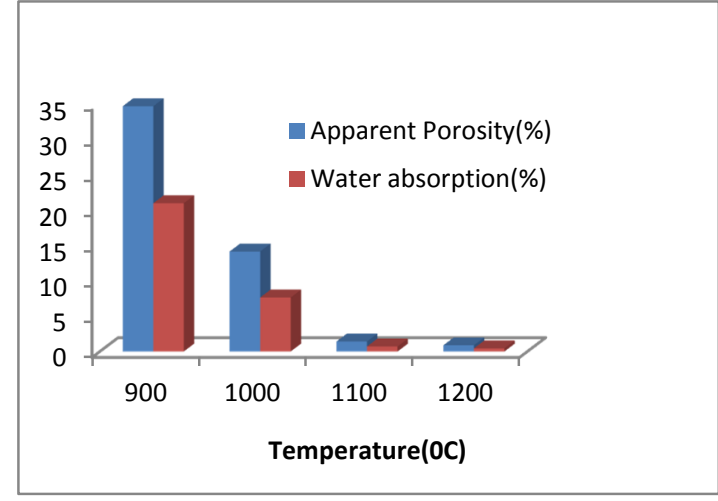

Fig 3: water absorption (WA) and Apparent porosity (AP) The decrease in porosity with increase in temperature indicates more closure of pores. At $1200^{\circ} \mathrm{C}$, very low porosity $(0.88 \%)$ was observed which may encourage the entrapment of gases which can cause cracking of the products or pin-holing if used as a glaze material. The low porosity also means poor thermal shock and little or no refractory applications. For domestic utilization and electrical insulation, low porosity is an advantage but for thermal insulation application, porosity is desired.

Water absorption: The plot is shown in figure 3. A decrease in Water absorption with increase in temperature from $900^{\circ} \mathrm{C}$ to $1200^{\circ} \mathrm{C}$ is observed. Water absorption measures the amount of water the sample is likely to retain in its body matrix. The value of $0.44 \%$ for the clay falls below the recommended value of 2.6-2.7\% (Chester, 1973). The lower the water absorption, the better the body for sanitary and culinary applications.

Bulk density: Bulk density (B.D) generally increases with increase in compaction. The plot for the B.D is shown in figure 4 .

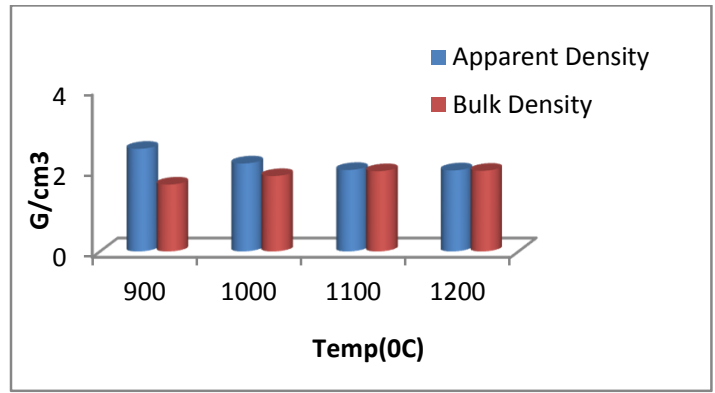

Fig 4: Bulk Density (BD) and Apparent Density (AD)

The value of $1.99 \mathrm{~g} / \mathrm{cm}^{3}$ was within the internationally accepted range of $1.7-2.1 \mathrm{~g} / \mathrm{cm}^{3}$ for building and fireclays (Lawal and Abdullahi, 2010). The increase in B.D with increase in temperature is due to increase in compaction and closure of pore spaces. Also formation of impervious glassy phase helps to seal up the pores and increase the B.D.

Apparent density: Apparent density (A.D) accounts for the volume of closed pores as well. A.D is the mass divided by its apparent volume. The value of 2.01 at $1200^{\circ} \mathrm{C}$ which decreases with increase in temperature is still within the range of $2.3-3.5 \mathrm{~g} / \mathrm{cm}^{3}$ being the internationally accepted standard range (Gbadebo, 2002). With increase in temperature, compression of particles occurs since organics, entrapped gases and liquids are evicted creating pores. Also other thermally unstable non-fuse able components are either decomposed or ejected creating holes or pores. As the spaces are closed up and particles forced together, the A.D will decrease. This compaction will impact on the bulk density which will increase with decrease in A.D as shown in figure 4

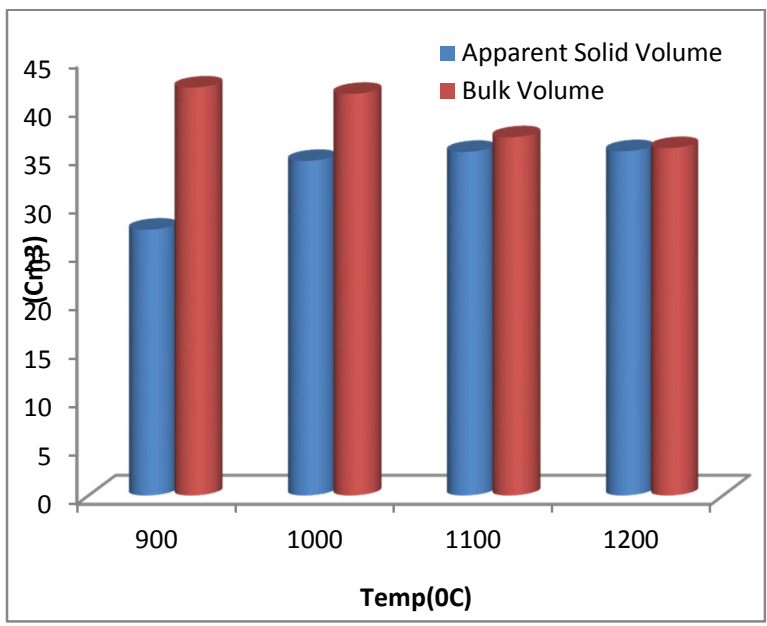

Fig 5: Apparent Solid Volume and Bulk Volume

Refractoriness: Value obtained is shown in Table 2. The value was too low $\left(1350^{\circ} \mathrm{C}\right)$ for the clay to be considered suitable for refractoy $\left(1500^{\circ} \mathrm{C}\right.$ and above) . The low value may be due to the effect of fluxing oxides on the alumina-silica bonding. The presence of $\mathrm{CaO}, \mathrm{MgO}, \mathrm{K}_{2} \mathrm{O}$ and $\mathrm{Fe}_{2} \mathrm{O}_{3}$ which are all very strong fluxes will pull down the vitrification temperature of the clay, making it unsuitable for refractory applications.

Cold crushing strength: Value obtained at $900^{\circ} \mathrm{C}$ was $1430 \mathrm{KN} / \mathrm{M}^{2}$ which is below standards for refractories, fireclays and high temperature Ceramics applications.

Making moisture: The test gives information on the strength and plasticity of the clay. It is however affected by the amount of water used to achieve moldability. High values show expansive and plastic clays while low values indicate that the clay is short. It is the moisture content corresponding to the plastic 
limit of a clay. Value obtained was $36.75 \%$ considered high to classify the clay as expansive and plastic.

Modulus of plasticity: This test gives information on the workability and also green strength of the clay. The closer the value to unity, the stronger the clay. The value for the clay was 1.36 , considered close enough to declare the clay strong.

XRD analysis: Figure 5 shows the X-ray diffraction of the sample.

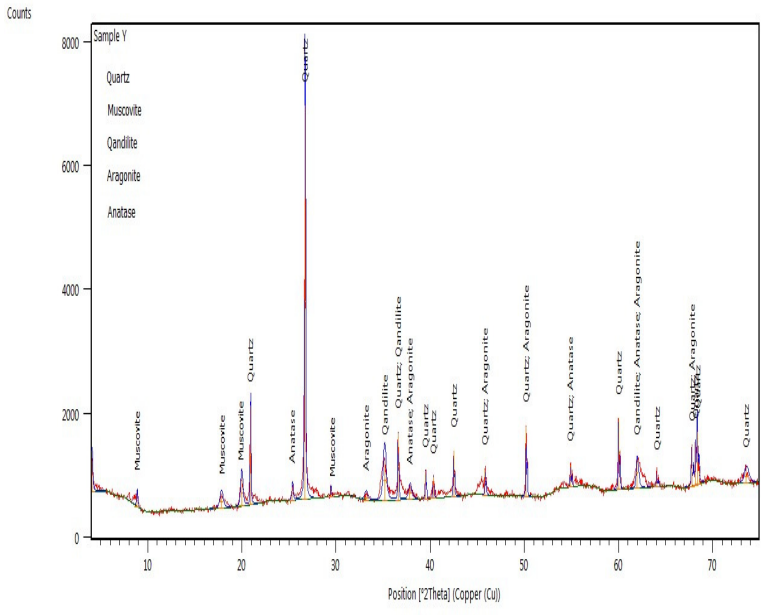

Fig 5: XRD spectra of Nkpuma Akpatakpa Clay.

Five major minerals are seen as the major component of the clay. They include Quartz, Muscovite, Qandilite, Aragonite and Anatase. The presence of these minerals in the clay may account for the fired colour of the clay which was ox-blood. Qandilite $\left(\mathrm{Mg}_{2} \mathrm{TiO}_{4}\right)$ with the usual cubic spinel structure $(F d 3$ $-m)$ is known to undergo a phase transition on cooling at $\sim 1000^{\circ} \mathrm{C}$ to a tetragonal modification $(P 4122)$, in which $\mathrm{Mg}$ and $\mathrm{Ti}$ are ordered onto distinct octahedral sites (Wechster and Navorotsky, 1984; Millard et al., 1995). $\mathrm{Mg}_{2} \mathrm{TiO}_{4}$ was found to breaks down to $\mathrm{MgTiO}_{3}$ (geikielite) plus $\mathrm{MgO}$ (periclase) with increasing pressure, according to the invariant reaction (Akimoto and Ayono, 1967; Oneill et al., 2005).

$\mathrm{Mg}_{2} \mathrm{TiO}_{4}=\mathrm{MgTiO}_{3}+\mathrm{MgO}$
Qandilite is black and has a black streak. It is brittle, opaque and strongly magnetic. Muscovite $\left[(\mathrm{KF})_{2}\left(\mathrm{Al}_{2} \mathrm{O}_{3}\right) 3\left(\mathrm{SiO}_{2}\right)\right]$ is a Monoclinic structured $\mathrm{C} 2=$ c(2M1) white streak with a vitreous to pearly or silky luster. Aragonite $\left(\mathrm{CaCO}_{3}\right)$ is an Orthorhombic or pseudo-hexagonal Pmcn space white streak with a Vitreous, resinous on fracture surfaces luster. Anatase $\left(\mathrm{TiO}_{2}\right)$ is a tetragonal structure, White to pale yellow streak with Adamantine to splendent, metallic luster and a I4/amd (synthetic) space which has a White to pale yellow streak.

SEM analysis: Figure 6 shows the microstructure of the clay.
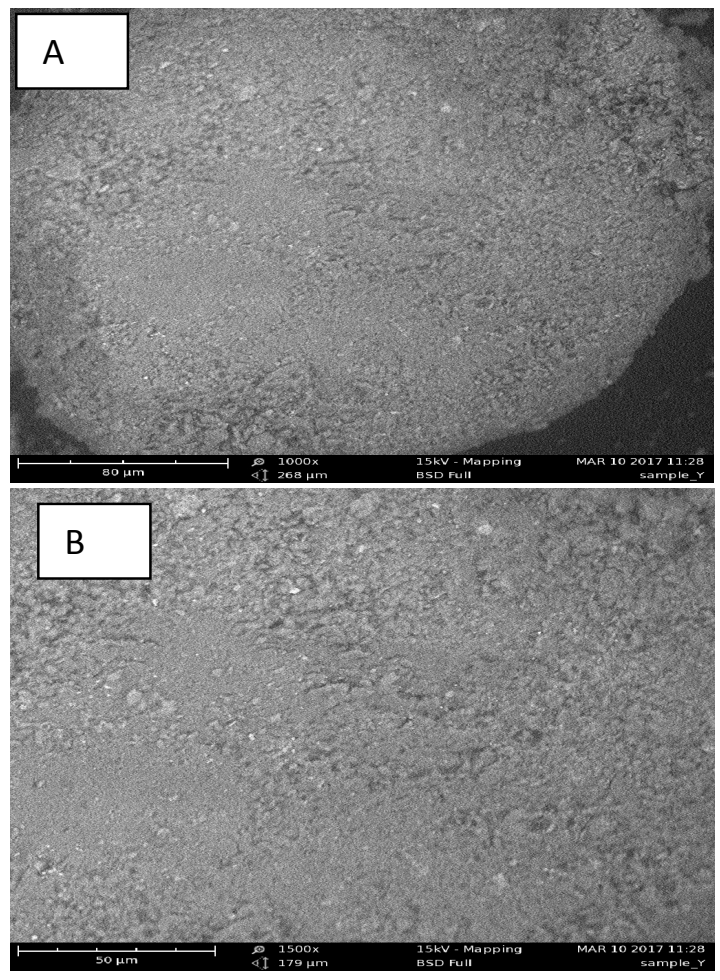

Fig 6.0: SEM of Nkpuma-Akpatakpa (A) $80 \mu \mathrm{m}$ (B) $50 \mu \mathrm{m}$

The surface morphology exhibits granulated surface texture probably due to the oxides interaction. The microstructure is characterized by the occurrence of smaller grains, high contact surface and consequently, decrease in porosity and water absorption when sintered 
FTIR analysis: Figure 7 shows the FTIR spectra of the raw N.A-Clay.

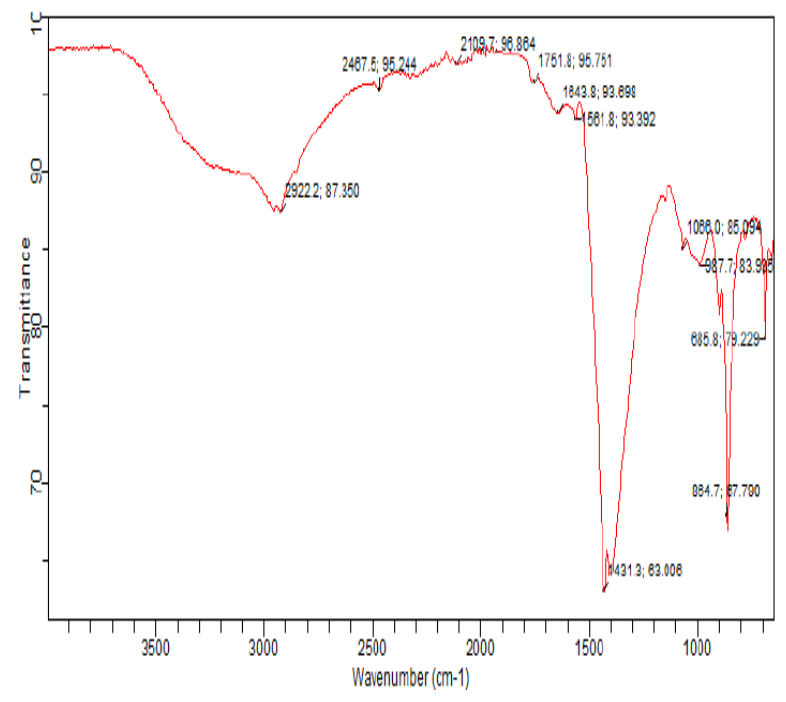

Fig 7: FTIR spectra of Nkpuma Akpatakpa clay

The clay shows absorptions at $1643.8 \mathrm{~cm}^{-1}$ which represents $-\mathrm{OH}$ bending vibrations and can also be assigned to the COO- symmetric stretching vibration (Li et al., 2011). The stretching vibrations for $\mathrm{Si}-\mathrm{O}$ were observed at $685.8 \mathrm{~cm}^{-1}$ showing the presence of Quartz. The frequency at $1431 \mathrm{~cm}^{-1}$ is due to $\left(\mathrm{CO}_{3}\right)^{2-}$ stretching mode vibration or $\mathrm{C}-\mathrm{O}$ stretching of Aragonite and the band at 2467.6 is due to $\mathrm{OH}$ stretching (Hunt et al., 1950; Huang and kerr, 1960). Bands observed at 984.7 and $987.7 \mathrm{~cm}^{-1}$ correspond to $\mathrm{Al}-\mathrm{O}$ bending vibrations which suggest the presence of muscovite in the clay. The absence of absorption frequencies of $433 \mathrm{~cm}^{-1}, 938 \mathrm{~cm}^{-1}, 1623 \mathrm{~cm}^{-1}, 3623$ $\mathrm{cm}^{-1}, 3695 \mathrm{~cm}^{-1}$ and $3735 \mathrm{~cm}^{-1}$ shows that the clay does not contain kaolinite. Vibrational frequency at $2921 \mathrm{~cm}^{-1}$ is due to $\mathrm{C}-\mathrm{H}$ symmetric stretching mode vibration of organic Carbon. Also, the band could be due to $-\mathrm{CO}_{3}$ stretching of Aragonite (Kumar et al.,2013).

Conclusions: From the result obtained, the clay contains five major minerals which are Quartz, Anatase, Aragonite, Muscovite and Qandilite. The physical characterization shows that the clay is not suitable for refractory and thermal insulation but suitable for ceramics applications especially where strength and low porosity are desired. The chemical profile shows elevated levels of $\mathrm{Fe}_{2} \mathrm{O}_{3}$ and other fluxing oxides which makes the clay unsuitable for electrical insulation applications but very suitable as stabilizer for earthenware glazes.

\section{REFERENCES}

Abubakar,I;BirninYauri.A;Faruq,U.Z;Noma,S.S; Sharif, N (2014). Characterization of Dabagi Clay deposit for its Ceramics Potential.Afr. J. Environ. Sci. Technol. 8(8):455 - 459.

Abuh,M.A;Abia-Bassey,N;Udeinya,T.C; Nwannewuihe,H.U; Abong,A.A;Akpomie, K.G (2014). Industrial Potentials of Adiabo Clay in Calabar Municipal of Cross River State, SouthSouth Nigeria.Pacific J. Sci. Technol. 15(1):6375 .

Akimoto, S;Syono, Y (1967): High-pressure decomposition of some titanatespinels. J. Chem. Phys., 47: 1813-1817

Benneth, C. C(2008). Settling Behavior of Kaolinite Clay in the Absence of Flocculants.Pacific J. Sci. Technol. 9(1): 21-28.

Chester, J. H( 1973). Refractories, Production and Properties.The iron and steel institute, 3-13, 295314.

Elueze,A.A; Ntekini,E.E; $\quad$ Ekwere,J.J(1999). Compositional and Industrial Assessment of Clay Bodies in Itu Area, South Eastern Nigeria.J. Min. Geology. 35(2):117-124.

Fakolujo, O. S; Olokode, O. S; Aiyedun, P. O; Oyeleke, Y. T; Anyanwu, B. U; Lee, W. E (2012). Studies on the Five (5) Selected Clays in Abeokuta, Nigeria. Pacific. J. Sci. Technol. 13(1):83-89.

Gbadebo, A.M(2002). Evaluation of Engineering and Industrial Potentials of Tidal Flat Clays in parts of Niger Delta, Nigeria.Niger. J. Eng. Res. Develop. 1(3): 20-27.

Grimshaw, R.W(1971). The chemistry and Physics of Clay and Allied Ceramics materials, $4^{\text {th }}$ ed, revised, New York: Wiley in Conscience. P. 15.

Gupta, O.P(2008). Elements of fuels furnace and refractories, $5^{\text {th }}$ edition, second reprint, kharnna publishers; New Delhi.

Huang,C.K; Kerr,P.E(1960). Infrared study of the carbonate materials, Am.J. of Mineral, 45: 311 - 324. 
Hunt, J. M;Wisherd, M.P; Bonham L. C(1950). Infrared absorption spectra of minerals and other inorganic compounds.Anal. Chem., 22:14781497.

Irabor, P.S.A (2002). Physical and Chemical Investigation on some Nigerian Kaolinite Clays for use in the Ceramics and Allied Industries.Niger. J. Eng. Res. Develop. 1(1):5459.

Kumar R. S;Rajkumar P. (2013).Characterization of Minerals in air dust particles in the state of Tamilnadu, India through FTIR Spectroscopy.Inter. J. Sci. Res. Technol. 2:7-13.

Lawal, A.O;Abdullahi.Y(2010). Evaluation of Industrial Potentials of Alluvial Clays from the Confluence of Rivers Niger and Mimi.Sci. World J. 5(3):213-221.

Li, Y; Xia, B; Zhao, Q; Liu,F; Zhang,P; Du,.Q.J(2011). Removal Of copper ions from aqueous solution by calcium alginate immobilized kaolin,.J. Environ. Sci. 23: 404-411.

Millard, R.L; Peterson, R.C; Hunter, B.K. (1995): Study of the cubic to tetragonal transition in $\mathrm{Mg} 2 \mathrm{TiO} 4$ and $\mathrm{Zn} 2 \mathrm{TiO} 4$ spinels by $17 \mathrm{O}$ MAS NMR and Rietveld refinement of X-ray diffraction data. Amer. Mineral., 80: 885-896.
Musa, U;Aliyu,M.A; Mohammed I.A; Sadiq,M.M.A (2012). Comparative study on the refractoy properties of selected clays in North Central Nigeria.Acad. Res. Inter. 3 (1): 23-27.

Nwannenna,O; Ogunro,A; Apeh,F(2015). Comparative Study on the Addition of Cullet to Mowe and Ibamajo Clay for ceramic tiles production. Chem.mater.Res, 7(4): $16-25$.

Omowunmi,O.J(2000). Characterization of some Nigerian Clays as refractory materials for furnace lining, Niger. Found.of Eng Manage, 3: $1-4$.

Oneill,O; Hugh,C.S; Scott,D.R(2005). The free energy of formation of $\mathrm{Mg} 2 \mathrm{TiO} 4$ (synthetic qandilite), an inverse spinel with configurational entropy, Eur.J. Mineral.17, 315 - 323.

Singer, F; Singer S (1993). Industrial Ceramic, London Chapman and Hill Limited.Pp. 234.

Wechsler, B.A; Navrotsky, A (1984): Thermodynamics and structural chemistry of compounds in the system $\mathrm{MgO}-\mathrm{TiO}_{2}$. J. Solid State Chem., 55, 165-180. 